\title{
REVIEW \\ Lauren Faulkner Rossi \\ Wehrmacht Priests: \\ Catholicism and the Nazi War of Annihilation
}

(Cambridge: Harvard University Press, 2015)

Martin R. Menke, Rivier University

Lauren Faulkner Rossi's book is a rich study of German Catholic clergy and seminarians under Nazi rule, especially during World War II. She embeds the specific experience of Catholic military chaplains and other Catholic priests and seminarians drafted for service within the larger discussion of the tension between Catholic moral teaching and German nationalist and National Socialist ideology. On a larger scale, Faulkner Rossi provides a useful case study with which to analyze the competing claims of national and religious identity on German Catholics in the twentieth century. She demonstrates that the pull of national identity and the pull of religious identity both were strong. She also shows that observant Catholics need not have been ideologically committed to Nazism to participate in the racial war in Eastern Europe.

Faulkner Rossi's work is a part of a growing scholarly analysis of German Catholic priests during the Nazi era. Other recent works include Kevin Spicer's Hitler's Priests: Catholic Clergy and National Socialism (DeKalb: Northern Illinois Press, 2008), Doris Bergen's Swords of the Lord: Military Chaplains from the First to the Twenty-First Century (South Bend: University of Notre Dame Press, 2004), and Martin Röw's Militärseelsorge unter dem Hakenkreuz: Die katholische Feldpastoral 1939 - 1945 (Paderborn: Ferdinand Schöningh, 2014). Of these, Faulkner Rossi offers the best analysis of Catholic priests and seminarians in the Wehrmacht. Lest one think this topic insignificant, one needs to remember that while there were never many more than four hundred active 
duty chaplains, a total of more than 17,000 priests, brothers, and seminarians served as medics. Church leaders constantly feared the anti-clerical and anti-religious indoctrination of the regime, and the Nazi regime took very seriously the danger Catholic vocations posed to Nazi ideology. These men faced these sometimes competing demands to carry out their religious vocations and to fulfill their duty to their homeland.

In the first chapter, Faulkner Rossi offers an outstanding summary of relations between the Catholic Church and the German imperial, republican, and Nazi governments. Explaining the tension between the Catholic minority and the largely Protestant elite dating back to before the Kulturkampf, this chapter presents perhaps the best brief summary of the subject. It is clear that Faulkner Rossi understands the larger developments in German Catholicism as well as the specific seminal moments and developments. Helpful to the reader also is Faulkner Rossi's gift of clear and engaging prose.

In the Catholic chaplaincy, one of the most important individuals was its vicar general, Georg Werthman. Faulkner Rossi uses his papers to explore the tensions between obedience to military and civilian authority and to Catholic teaching. She does so in a more differentiated manner than others have. While some have seen Werthmann as almost heroic for taking on most of the duties of the ineffective Military Bishop Justus Rarkowsky, Faulkner Rossi points out Werthmann's moral blind spots. An example of this is his unquestioned loyalty to the armed forces, even insisting on wearing his military uniform while in post-war American captivity and forbidding Catholic clergy from aiding occupation officials after defeat.

Throughout the work, Faulkner Rossi builds on the ideas John Connelly developed in his From Enemy to Brother (Cambridge: Harvard University Press, 2012). She asks how Catholics could support, tolerate, or simply not resist a regime that was not only immoral but manifestly inimical to Catholic teachings and the Church. Only one priest, Pallotine father Franz Reinisch, died for his refusal to serve in the Wehr- 
macht. While Faulkner Rossi argues that for every priest who resisted Nazi demands, there were many more priests who accommodated themselves to the regime and even a good number of "brown" priests who supported the regime out of conviction, she is more interested in understanding than in keeping score. Given the incompatibility of Catholic morality and Nazi ideology, Faulkner Rossi inquires how Catholics reconciled themselves to the regime before and during the war. She shows that Catholics, like most people, were patriotic, often nationalistic, but also observant of their faith and reliant on the comfort it provides in a crisis. In other words, German Catholics live their faith as well or as poorly as people of all other faiths and nationalities.

Like Röw, Faulkner Rossi problematizes the use of the Sacrament of Reconciliation in wartime. On the one hand, immoral acts are part of warfare. However, this war was intentionally and profoundly immoral since the regime declared the war in the East to be a racial war in which the rules of war did not apply. As a military chaplain, how could one grant absolution to a Wehrmacht soldier who had participated in mass murder or other atrocities beyond the "normal" scope of wartime horror, considering that the same soldier was likely to commit further crimes in service to the Fatherland.

Faulkner Rossi embeds this wartime experience and behavior in the context of the pre-war formation of Catholic clergy during the early period of Nazi rule. She shows that the wartime priests had been well-socialized in a dense network of Catholic youth organizations that had survived until the late thirties. They were immersed not in Nazi ideology from birth but had gone through Catholic formation. Their seminary training occurred largely free of Nazi influence. One might have expected these men not only to be "inoculated" against Nazi racism and violence, but to see it as their Christian duty to speak out against such crimes.

Another process in the development of Catholic-Nazi relations that Faulkner Rossi explains well is the increasing persecution 
of the Church by the regime. From the violations of the Reich Concordat almost immediately after its conclusion, to the morality and currency fraud trials of the later thirties, to the ban on Catholic youth organizations, Faulkner Rossi shows the regime's increasingly vehement efforts to remove the Church from public life. When the war broke out, there were no chaplains in the air force, established after the Concordat's conclusion, and of course, no chaplains in the SS. Furthermore, the regime vetted all candidates for the chaplaincy. The Nazis soon dismissed all Jesuits from military service, and then dismissed all priests from the reserve officer corps. There never were enough chaplains to meet demand, and the efforts of priests who served as medics to fill the pastoral gap were tightly controlled and discouraged by the Nazis. By 1942, the regime insisted that empty chaplains' posts were not to be filled, even after 19 chaplains died or became captives at Stalingrad. At the same time, the regime introduced the Nazi equivalent to the Soviet Politkommissar, the Nationalsozialistische Führungsoffizier to provide proper indoctrination.

Faulkner's historical interrogation of Catholic chaplains does not end in 1945. She analyzes post-war accounts by priests reflecting on their wartime service. None acknowledge the contradictions between what many observed themselves or at least heard in the confessional and Catholic morality. None mention having seen atrocities themselves or having suffered under the burden of such knowledge. It is as if the Holocaust did not occur within their realm of responsibility. Faulkner explores antisemitism among the chaplains, but finds few active antisemites. She shows that, even retrospectively, German Catholic priests largely saw the atrocities in the East as something that happened outside their area of influence and responsibility.

The only minor quibble one could have with this work, and it is a minor quibble, is one infelicitous translation from the German on page 249, where Faulkner Rossi translated "oder ihm auch nur die Augen zudrücken" as "to be able to bend the rules for him." "Eine Auge zudrücken” indeed means to 
bend the rules to let something pass, but "jemandem die Augen zudrücken" is the practice of closing the eyelids of someone just deceased, which also makes more sense in the context of the passage.

Faulkner Rossi's work is valuable. She provides an excellent summary of Catholic relations with the German state and with the Protestant majority before 1933, then uses the chaplaincy to illustrate the immensely complex relationship between the Church, its priests, and its members on one hand and the Nazi regime and the Wehrmacht on the other, from the beginning to the end of the regime. Furthermore, she confirms that after the war, German priests were as unlikely as lay people to critically reconsider their service to Germany and its masters in the light of Catholic morality, even after Vatican II. Her work is suitable for the larger public, undergraduates, graduate students, and scholars. The question of the competing loyalties of faith and nation in the face of such atrocities remains, but Faulkner Rossi has provided much food for thought. 